\title{
Cristãos-novos, inquisição e escravidão: Ensaio sobre inclusão e exclusão social (Alagoas Colonial, $1575-1821)^{1}$
}

\section{New Christians, inquisition and slavery: Essay about social inclusion and exclusion (Colonial}

Alagoas, 1575-1821)

\author{
Alex Rolim Machado²
}

Resumo: A história concernente a "Alagoas Colonial" se encontra atualmente em pesquisa e divulgação. Nesse ponto, os assuntos relacionados aos cristãos-novos são lacunares, tendo aparições apenas de maneira esporádica em outras obras. 0 intuito desse artigo é trazer os personagens às novas interpretações, inserindo-os em um mundo multifacetado, de intensa comunicação com as outras categorias sociais das Vilas. Pretende-se observar os polos de inclusão e exclusão aos quais estavam sujeitos e, por decorrência da vivência americana, também atuavam na estratificação da sociedade.

Palavras-chave: Cristãos-novos. Inquisição. Alagoas Colonial

Abstract: The history concerning about the "Colonial Alagoas" is en-against currently in research and dissemination. At this point, the issues of New Christians are deficient, with appearances only sporadically in other works. The purpose of this paper is to study the New Christians to new interpretations by entering them in a multi-faceted world of intense communication with other social categories. It is intended observe the inclusion and exclusion poles to which the new Christians were subject and, as a consequence of the American experience, also worked in the stratification of society.

Keywords: New Christians. Inquisition. Alagoas Colonial

Para os cristãos da época medieval e moderna, os judeus foram os autores do maior crime "da história da humanidade" - o deicídio - e, por tal motivo, teriam sido perseguidos durante séculos nos

\footnotetext{
1 Texto inicialmente apresentado no VI Encontro Nacional de História - UFAL, no Simpósio 7: Escravidão, mestiçagens e relações de poder no Brasil (Séculos XVI ao XIX), coordenado pelos Doutores Gian Carlo de Melo Silva (UFAL) e Antonio Filipe Pereira Caetano (UFAL), sob o título "Cristãos-novos em Alagoas Colonial: Inquisição, escravidão e costumes lusobrasileiros". Agradeço as colocações do Prof. Dr. Gian Carlo de Melo Silva sobre as ideias apresentadas, bem como as falas e leitura atenta do texto pelo Prof. Dr. Antonio Filipe Pereira Caetano. Deixo ainda agradecimentos pela leitura atenciosa e crítica da Prof. Dr. Irinéia Franco dos Santos e de Anne Karolline Campos Mendonça. Da mesma feita, agradeço às colocações dos pareceristas, que foram extremamente pacientes, prestativos e respeitosos ao meu estilo de escrita. As ideias finais apresentadas nesse ensaio (assim como possíveis omissões) são de inteira responsabilidade minha. 2 Bacharel em História pela Universidade Federal de Alagoas. Atualmente mestrando pelo programa de pós-graduação em História da Universidade Federal de Alagoas. Bolsista CAPES. Membro do Grupo de Estudos América Colonial (GEACUFAL), coordenado pelo Prof. Dr. Antonio Filipe Pereira Caetano.
} 
espaços europeus ${ }^{3}$. Em Portugal se estabeleceram formando comunidades sefarditas. Atuaram nas redes de comércio e como mercadores de grosso trato. Financiavam projetos, eram intelectuais, advogados, cirurgiões, boticários, etc. Com a conversão forçada em 1497 (tornando os judeus em "cristãos-novos") e a institucionalização da Inquisição em 1536, os praticantes da moral, costumes e leis de Moisés, se tornaram constantemente vigiados e castigados nos espaços lusos. Não podiam se candidatar a cargos públicos, certos privilégios não estavam ao seu alcance, a discriminação "racial" (pelos estatutos da "pureza de sangue") era latente e muitos foram perseguidos e mortos durante 0 primeiro século de funcionamento do Tribunal português. Seus bens foram confiscados, famílias arruinadas e tantas fugiram para outros espaços europeus, sem saberem se seriam bem recebidas 4 .

Com o advento das primeiras conquistas e da expansão marítima portuguesa, que teve os cristãos-novos como financiadores de expedições, houve uma quantia considerável de empreendimentos dessa "nação" 5 em terras americanas ${ }^{6}$. Apareciam como pessoas ricas que adquiriram posses e fundaram engenhos, começando a moer a cana para produzir açúcar para o mercado mundial. Esse comércio tinha seus agentes cristãos-novos lusos, que cuidavam de pequenas agências e ligações entre América portuguesa, Portugal e outras praças mercantis como Londres e

\footnotetext{
${ }^{3}$ Não apenas por isso, mas por diversos outros "atributos" relacionados a eles. REGO, João Manuel Vaz Monteiro de Figueiroa. $<<A$ honra alheia por um fio $>$. Os estatutos de limpeza de sangue no espaço de expressão lbérica (sécs. XVIXVIII). Tese de Doutoramento em História Moderna. Minho: Universidade do Minho, Instituto de Ciências Sociais, 2009, pp. 20 e seguintes.

${ }^{4}$ SALVADOR, José Gonçalves. Cristãos-novos, jesuitas e Inquisição: Aspectos de sua atuação nas capitanias do Sul, 1530-1680). São Paulo: Livraria pioneira editoria; Editora da Universidade de São Paulo, 1969, p. 17. VAINFAS, Ronaldo. Jerusalém colonial: judeus portugueses no Brasil holandês. Rio de Janeiro: Civilização Brasileira, 2010, pp. 26 e seguintes. NOVINSKY, Anita. Inquisição: Prisioneiros do Brasil, séculos XVI a XIX. 2 edição revisada. São Paulo: Perspectiva, 2009, p. 24-25. PEDREIRA, Jorge M. Custos e Tendências Financeiras do Império Português, 1415-1822. In: BETHENCOURT, Francisco. CURTO, Diogo Ramada. (dir.) A expansão marítima portuguesa, 1400-1800. Lisboa: edições 70, 2010, p. 57, 64. BOXER, Charles. O império marítimo Português. 1415-1825. São Paulo: Companhia das Letras, 2002, pp. 25-26, 279-285. HERMANN, Jacqueline. Cristãos-novos. In: VAINFAS, Ronaldo (org.). Dicionário do Brasil colonial (1500 - 1808). Rio de Janeiro: Objetiva, 2001, p. 149. VAINFAS, Ronaldo. Inquisição. In: VAINFAS. Op. Cit., 2001, p. 308. BETHENCOURT, Francisco. História das inquisições: Portugal, Espanha e Itália. Lisboa: Circulo de Leitores, 1994, p. 22, 261-263, 279, 297. SIQUEIRA, Sonia. A inquisição portuguesa e a sociedade colonial. São Paulo: Ática, 1978. RUSSELL-WOOD, A. J. R. Padrões de colonização no Império português, 1400-1800. In: BETHENCOURT. CURTO. (dir.) Op. Cit., 2010. p. 172, 197. Necessária, para se entender a colocação do termo "racial", a leitura completa do livro de CARNEIRO, Maria Luiza Tucci Carneiro. Preconceito racial em Portugal e Brasil colônia: os cristãos-novos e o mito da pureza de sangue. São Paulo: Perspectiva, 2005.

5 "O termo nação, desde os primeiros tempos de monarquia em Portugal, vinha associado à palavra judeu, pelo fato deste ser considerado um grupo à parte, vivendo em judiarias ou judarias. A expressão 'Gente da Nação Hebréia', e por elipse de linguagem 'Gente da Nação', continuou a ser empregada mesmo após a conversão forçada dos judeus em 1497 como referência aos cristãos-novos. Nos processos de habilitação de Genere, a palavra nação aparece sempre com sentido pejorativo, qualificada pelo termo infecta. Assim, é comum encontrarmos a seguinte expressão: 'o habilitando é christãovelho sem raça alguma de judeu, mouro, mourisco, mulato, christão-novo, herege ou de outra qualquer infecta nação das desaprovadas em Direito contra nossa Sancta Fé Catholica'". CARNEIRO. Maria Luiza Tucci. Preconceito racial em Portugal e Brasil colônia: os cristãos-novos e o mito da pureza de sangue. São Paulo: Perspectiva, 2005, p. 268.

${ }^{6}$ BOXER. Op. Cit., 2002, p. 282. BETHENCOURT. Op. Cit., 1994, pp. 265-266. PRADO, J. F. de Almeida. O regime das capitanias. In: HOLANDA, Sérgio Buarque de (dir.). História Geral da Civilização Brasileira: A época colonial. Tomo I, do descobrimento à expansão territorial. São Paulo: Difusão Européia do Livro, 1960, pp. 106-107. HERMANN. Op. Cit., 2001, p. 150. NOVINSKY. Op. Cit., 2009, pp. 26-27.
} 
Amsterdam. Entretanto, o outro lado da moeda existiu e a perseguição contra os cristãos-novos, a partir da Inquisição, foi fomentadora de fuga de capitais em diversos empreendimentos ${ }^{7}$.

Por conta dos impedimentos e das barreiras que eram dadas aos cristãos-novos, é comum associá-los aos ofícios (citados acima) já consagrados na historiografia. Muito disso foi comum, visto os relatos de época e expressões costumeiras da Europa na América espanhola ${ }^{8}$, principalmente no mundo dos negócios, onde mercador era tratado como sinônimo de judeu ${ }^{9}$ Nos espaços americanos, visto que uma sociedade estava "se fazendo"10, houve tentativas (com seus sucessos e fracassos) dos judeus convertidos ao cristianismo conseguirem adentrar nas dinâmicas que no Reino sua probabilidade de participação era reduzida ${ }^{11}$.

Para compreender esses novos relacionamentos é interessante ter em mente que as ações sociais (a cultura, para Edward Thompson), devem se tornar dialéticas com a experiência vivida, matéria prima do historiador. Ora, os cristãos-novos, enquanto agentes históricos se reproduzem socialmente e materialmente. Porém, sem deixar de lado outras relações que mantinham ou transformavam, como as obrigações familiares, parentescos, sentimentos, moral. Essa vivência sempre implicará escolha de valores. Mesmo que tais valores possam ser impostos a pessoa, nunca serão

\footnotetext{
7 VAINFAS. Op. Cit., 2001, p. 309. SCHWARTZ, Stuart. Segredos internos: engenhos e escravos na sociedade colonial, 1550-1835. São Paulo: Companhia das Letras, 1988, p. 225. NOVINSKY. Op. Cit., 2009, p. 21, 25. Apesar de difícil, houve na Bahia dois cristãos-novos presos que estavam inseridos no tráfico de escravos, idem, p. 42. BETHENCOURT, Francisco. CURTO, Diogo Ramada. Introdução. In: BETHENCOURT. CURTO. Op. Cit., 2010, p. 15. Essa ideia da Inquisição portuguesa como um "freio anti-capitalista" pode ser vista em GODINHO, Vitorino Magalhães. 1580 e a Restauração. In: GODINHO, Vitorino Magalhães. Ensaios II, sobre a história de Portugal. Lisboa: livraria Sá da Costa Editora, 1968, pp. 279281. Francisco Bethencourt alertará que essa posição maquiavélica de perseguição contra os cristãos-novos ("a fabricação de Judeus") deve ser revista e posta em estudos empíricos mais aprofundados, cf. BETHENCOURT, Francisco. A Inquisição revisitada. In: GARRIDO, Álvaro. COSTA, Leonor Freire. DUARTE, Luís Miguel (org.). Economia, Instituições e Império. Estudos em homenagem a Joaquim Romero Magalhães. Coimbra: Almedina, 2012, p. 153. Para o caso de Alagoas, levou-se esse argumento para tentar compreender que muitos mercadores "alagoanos" se habilitaram para serem Familiares do Santo Ofício entre 1672 e 1820, tentando almejar status social como fugir do estigma do "sangue judeu", cf. MACHADO, Alex Rolim. Mercadores da inquisição. Notas sobre estratégias de ascensão social (Alagoas Colonial, c.1674c.1820). Historien (Petrolina). Ano 4, no 9. Jul/Dez 2013. Acessado em www.revistahistorien.com

${ }^{8}$ BOXER. Op. Cit., 2002, p. 281, 284. ASSIS, Angelo Adriano Faria de. As "mulheres rabi" e a Inquisição na colônia: narrativas de resistência judaica e criptojudaísmo feminino - os Antunes, macabeus da Bahia (séculos XVI-XVII). In: VAINFAS, Ronaldo. FEITLER, Bruno. LAGE, Lana (org.). A inquisição em xeque: temas, controvérsias e estudos de caso. Rio de Janeiro: EdUERJ, 2006, p. 183.

${ }^{9}$ BOXER. Op. Cit., 2002, pp. 331-333, 346-347. TORRES, José Veiga. Da Repressão Religiosa para a Promoção Social. A Inquisição como instância legitimadora da promoção social da burguesia mercantil. In: Revista Crítica de Ciências Sociais, no 40, Outubro 1994, pp. 118-119. GIZBERT-STUDNICKI, Daviken. A Nação e o Império: o espaço da diáspora marítima portuguesa no Atlântico Luso-lbérico do século 17. In: SCHWARTZ, Stuart. MYRUP, Erik. O Brasil no império marítimo português. Bauru, Sp: Edusc, 2009, pp, 129-131. BOSCHI, Caio. Episcopado e Inquisição. In: BETHENCOURT, Francisco. CHAUDHURI, Kirti. (dir.) História da Expansão Portuguesa vol. III: O Brasil na Balança do Império (1697-1808). Lisboa: Temas e debates, 1998, p. 384. BETHENCOURT. Op. Cit., 1994, pp. 267-268.

10 Tomo aqui as colocações de Edward Thompson, de um "fazer-se" dinâmico, que persiste e muda de acordo com a vivência histórica das pessoas e de suas relações entre si ("Fazer-se, porque é um estudo sobre um processo ativo, que se deve tanto à ação humana como aos condicionamentos"), cf. THOMPSON, Edward. Formação da classe operária inglesa: vol. I, a árvore da liberdade. Rio de Janeiro: Paz e Terra, 1987, p. 9.

11 HERMANN. Op. Cit., 2001, p. 151. NOVINSKY. Op. Cit., 2009, p. 28. SCHWARTZ. Op. Cit., 1988, p. 229. SALVADOR. Op. Cit., 1969, p. XXIII. NOVINSKY, Anita. Os cristãos-novos no Brasil colonial: reflexões sobre a questão do marranismo. Tempo, n⿳11, Rio de Janeiro, p. 68.
} 
absorvidos cegamente ou acriticamente. Mesmo que o historiador não compactue do valor utilizado por aquele indivíduo, sua escolha se deu por conta de uma conjunção imensa de fatores de ordem conjuntural, estrutural, material, familiar, pessoal, local, imediato, histórico, etc. Portanto, estudar uma escolha de valor nunca deve ser dado por uma Teoria a-e-anti-histórica12, e sim pelo estudo daquela pessoa (ou grupo, ou classe) no seu tempo histórico e vida. Também não se deve cair no erro utilitarista de achar que tudo é por causa de um interesse material, apesar de que o estudo materialista desses "interesses" morais pode estar relacionado à "permanência material da cultura: o modo de vida, e acima de tudo, as relações produtivas e familiares das pessoas"13.

Estabelecer-se-á o artigo em três tópicos chaves para começar a analise dos cristãos-novos e dos cristãos-velhos: a) A Inquisição, que ajuda a demonstrar, mesmo com vários enviesamentos, como alguns desses descendentes dos judeus convertidos mantinham suas práticas, e por isso eram perseguidos $^{14}$. Igualmente, nem todos os cristãos-novos mantiveram práticas de sua religião, mas 0 estigma do sangue e de sua descendência foi constantemente reafirmado em acontecimentos locais, extrapolando as atividades do Tribunal. Observar as atitudes contra os cristãos-novos fora do eixo do Santo Ofício (mas possivelmente influenciado por ele) é um dos objetivos propostos desse ensaio b) A escravidão, como instituição que fez parte do cotidiano americano, extrapolou as atividades econômicas e atingiu as culturais, religiosas, sociais e políticas. $O$ cristão-novo não estava isento de seus malefícios que hoje são conhecidos e que, naquela época, era dado até mesmo como "divino". Ajudava a manter as distinções, aparências e os preconceitos de cor e distinções de sangue ${ }^{15}$. c) E 0 que denominarei de "costumes lusos"16. As ações influenciadas pela moral, cultura e vivência comum aos habitantes, que vigoravam nos casamentos, na política das Câmaras Municipais, nas confrarias religiosas e nas ações judiciais de Ouvidores e outros oficiais, fossem régios ou não. Seguindo a ideia da Inquisição, avaliar-se-á como tais costumes foram aceitos, a partir de seu poder simbólico,

\footnotetext{
${ }^{12}$ Nesse caso, a "teoria de Althusser" que Thompson tece suas críticas.

13 THOMPSON. Edward. A miséria da teoria, ou um planetário de erros: uma crítica ao pensamento de Althusser. Rio de Janeiro: Zahar, 1981, pp. 189-195.

${ }^{14}$ Sobre os perigos e "enviesamentos" das fontes, não necessariamente aos assuntos que tangiam apenas os cristãosnovos, mas quase todos aqueles questionados pela Inquisição, cf. GINZBURG, Carlo. 0 inquisidor como antropólogo: Uma analogia e as suas implicações. In: GINZBURG, Carlo. A micro-história e outros ensaios. Lisboa, Rio de Janeiro: Difel, Bertrand Brasil, 1989. BETHENCOURT. Op. Cit., 1994, pp. 295-297.

${ }^{15}$ CARDOSO, Ciro Flamarion. Escravo ou camponês?: o protocampesinato negro nas Américas. São Paulo: Brasiliense, 2004. E GORENDER, Jacob. $O$ escravismo colonial. $2^{a}$ edição. São Paulo: Editora ática, 1978. FARIA, Sheila de Castro. VAINFAS, Ronaldo. Escravidão. In: VAINFAS. Op. Cit., 2001, pp. 205-209. VAINFAS, Ronaldo. Ideologia e Escravidão: Os letrados e a sociedade escravista no Brasil colonial. Rio de Janeiro: Editora Vozes, [s/d]. Para Alagoas, cf. DIÉGUES Jr. Manuel. O banguê nas alagoas: traços da influência do sistema econômico do engenho de açúcar na vida e na cultura regional. $3^{\mathrm{a}}$ ed.; prefácio de Gilberto Freyre; capas e vinhetas de Santa Rosa. Maceió, EDUFAL, 2006.

16 Utilizo a denominação "luso" por conta da advertência de Serge Gruzinski: "Tampouco ibérico pode ser reduzido a uma mistura de muito Brasil com uma pitada de Oriente. A riqueza da categoria ibérica provém do patrimônio comum e único que representa diante do resto da Europa e da sua natureza eminentemente polimorfa, compósita e móbil, que deve ser constantemente redefinida". GRUZINSKI, Serge. Os canibais de Lisboa: da história colonial e imperial à história global. In: ALMEIDA, Suely. SILVA, Gian Carlo. RIBEIRO, Marilia. (orgs.) Cultura e sociabilidades no mundo atlântico. Recife: Ed. Universitária da UFPE, 2012, p. 30.
} 
adaptados e readaptados para impedir uma maior movimentação dos cristãos-novos dentro das dinâmicas sociais ${ }^{17}$.

O que se pretende nesse artigo é atentar às dinâmicas criadas e percorridas por alguns cristãosnovos em ações que envolviam a sociedade ao seu redor, pondo a observá-los em movimento nessa coletividade americana luso-brasileira. Movimentação que perpassava por dois polos: 0 de inclusão e o de exclusão ${ }^{18}$. 0 primeiro nas instituições mais comuns, com foco na escravidão e na mestiçagem. 0 segundo avaliando a perseguição sofrida, tanto no sentido repressor (Inquisição) como no simbólico (estatutos da pureza de sangue).

Sobre a inserção dos cristãos-novos nesse mundo escravista, salienta-se desde já que, muitos exemplos utilizados nesse trabalho, assim como algumas colocações, foram escritos e publicados em artigo anterior ${ }^{19}$. A justificativa é simples. A questão não é o documento. $E$, sim, a problemática que se traça em cima dele. Nesse caso, como já foi exposto, a sociedade luso-brasileira é escravista, tendo na inserção da cultura e da mão de obra escrava, do negro africano e do ameríndio, uma de suas bases primordiais, no entendimento das relações sociais que vai fundamentar parte importante da sociedade. Logo, pretende-se evidenciar que a história dos cristãos-novos em "Alagoas Colonial"20 deve ser sempre relacionada com a história dos negros, pardos, mulatos e ameríndios, por conta da escravidão e das miscigenações étnico-raciais e culturais, baseados nos intercâmbios e na violência. Essas histórias fazem parte também da história dos agentes do Santo Ofício inseridos naquela localidade, responsáveis pela perseguição e repressão a essas camadas subalternas e religiões tidas como heréticas. Sendo esses últimos fomentadores da estruturação e das hierarquias sociais, fortalecendo estigmas e estratificações ${ }^{21}$. Ou seja, uma história de inclusão (pertencimento a um estrato branco, muitas vezes alcançando posições de mando e dominantes, absorvendo as distinções pela "pureza de sangue") e exclusão (tratamento diferenciado por ser "raça de infecta nação", tornando-se uma camada subalterna em alguns espaços econômicos e completamente expulsos da vida política e religiosaadministrativa).

\footnotetext{
17 THOMPSON, Edward P. Costumes em comum. - São Paulo: Companhia das Letras, 1998, pp. 13-24. BOURDIEU, Pierre. Sobre o poder simbólico. In: BOURDIEU, Pierre. O poder simbólico. Rio de Janeiro: Bertrand Brasil, 2012.

${ }^{18}$ ISRAEL, Jonathan I. Judeus sefaradim neerlandeses, política milenarista e a luta pelo Brasil (1645-1654). In: SCHWARTZ. MYRUP. Op. Cit., 2009, p. 147 e seguintes.

${ }_{19}$ MACHADO, Alex Rolim. Classificação e perseguição: os agentes da Inquisição, os negros, pardos e mulatos em uma sociedade escravista (Alagoas Colonial, 1674-1820). Sankofa, Revista de História da África e de Estudos da Diáspora Africana, Ano VII, nº XIV, Dezembro /2014.

${ }^{20}$ Ao decorrer do trabalho, o termo "Alagoas Colonial" será sempre citado entre aspas, de acordo com a delimitação feita por Antonio Filipe Pereira Caetano. Cf. CAETANO, Antonio Filipe Pereira. "Existe uma Alagoas Colonial?" Notas preliminares sobre os conceitos de uma Conquista Ultramarina. Revista Crítica Histórica, Ano I, ñ 1, Junho/2010, p. 32. http://www.revista.ufal.br/criticahistorical (acessado no dia 16/05/2012).

${ }^{21}$ CALAINHO, Daniela Buono. Agentes da fé: familiares da Inquisição portuguesa no Brasil colonial. Bauru: EDUSC, 2006. Para "Alagoas Colonial", cf. MACHADO. Op. Cit., 2013.
} 
O recorte temporal é a questão mais delicada do trabalho. Optou-se pela data inicial de 1575 por ter sido ela, de acordo com Manuel Diégues Jr., a expedição das primeiras conquistas do território de Porto Calvo, por Cristovão Lins, "inaugurando" o empreendimento luso-brasileiro em terras ao sul de Pernambuco ${ }^{22}$. Em 1591, com a visitação da Inquisição em Pernambuco, começa-se a primeira caça aos cristãos-novos em território da Capitania. Logo, até que novas pesquisas apareçam, utiliza-se a primeira data para começar a pensar e arriscar a hipótese que alguns cristãos-novos podem ter contribuído na ocupação do espaço sul (não apenas como Senhores de Engenho, mas possivelmente lavradores, mercadores, artesãos). O período é próximo com a história do estabelecimento do Tribunal em Portugal em 1536, e do processo de institucionalização da estigmatização dos cristãos-novos, em 1514/1521, com as Ordenações Manuelinas, sendo que "essa situação se mantém até 1603, quando serão acrescentados o negro e o mulato"23. Da mesma feita, apesar do primeiro regimento dos Familiares do Santo Ofício ser de 1613, é em 1640 que ele aparece melhor sistematizado, pois a condição de não possuir "raça infecta" de judeu, mouro, africano ou ameríndio era um dos prestígios mais visados ${ }^{24}$. Todavia, o Marquês de Pombal, em sua administração, durante o reinado de Dom José, estabeleceu o fim da distinção entre cristãos-novos e cristãos-velhos em 1773, reformulando 0 regimento da Inquisição em 1774, excluindo dali a limpeza de sangue como condição indispensável aos pretendentes ao cargo. Contudo, uma lei não atua de imediato nos costumes da localidade. A discriminação e o estigma pelo Direito poderiam ter acabado, mas as tradições teriam continuado25. Por isso, utilizar-se-á como data final do ensaio o ano de 1821. Ou seja, o fim da Inquisição de Portugal selaria de vez (ou por hora) a perseguição institucional-religiosa contra aqueles que (na visão dos agentes da inquisição e de boa parcela da sociedade) iam de encontro com a religião católica, de tal modo como findava com a máquina policial de agentes do Tribunal. Entretanto, continuaram na "história do Brasil Império", a partir de renovadas relações socioeconômicas e étnico-raciais, as tradições de racismo e discriminação à camadas da sociedade que eram - e continuaram sendo em parte - subalternizadas. Logo, a data final desse ensaio não deve ser encarada como data final, e sim, como um "ponto final" em comum da história dos cristãos-novos, africanos e Inquisição.

No âmbito da historiografia, esse trabalho pretende esboçar algumas notas ensaísticas. $O$ intuito é expor um pouco a temática e sua pertinência para novas pesquisas. Na linha da história da ação

\footnotetext{
22 "Esta expedição ter-se-ia dado entre 1575 e 1585". DIÉGUES Jr. Manuel. O banguê nas alagoas: traços da influência do sistema econômico do engenho de açúcar na vida e na cultura regional. $3^{\text {a }}$ ed.; prefácio de Gilberto Freyre; capas e vinhetas de Santa Rosa. Maceió, EDUFAL, 2006, p. 51.

${ }^{23}$ CARNEIRO. Op. Cit., 2005, pp. 49-50.

${ }^{24}$ RODRIGUES, Aldair Carlos. Limpos de Sangue: Familiares do Santo Ofício, Inquisição e Sociedade em Minas Colonial. São Paulo: Alameda, 2011, pp. 103-104.

25 "As medidas legais contra o herege e 0 apóstata persistem. Tudo leva a crer que eram de origem cristã-nova numerosos portugueses que caíram, já às margens do século XIX, na alçada do Tribunal da Inquisição", CARNEIRO. Op. Cit., 2005, p. 50.
} 
inquisitorial, espera-se ajudar a compor o quadro dos trabalhos lacunares que foram desenvolvidos para "Alagoas"26, começando por Luiz Mott, em 1992, e só duas décadas depois retomado27. Outro ponto é o ineditismo de se ter em Alagoas uma pesquisa direcionada aos cristãos-novos e a comunidade judaica em geral, seja em qualquer época for e a temática proposta, seja vinculada à Inquisição ou não. Escrita essas primeiras linhas, passa-se ao desenvolvimento empírico do artigo.

\section{Esboço introdutório da história dos cristãos-novos em "Alagoas Colonial"}

Apesar de não ser o intuito desse trabalho estabelecer uma história da presença dos cristãosnovos em terras "alagoanas", é importante esboçar algumas ideias iniciais que obedeçam a três posições importantes: a) que os cristãos-novos não saíram do nada ou, por estarem inseridos na sociedade lusitana, não tenham uma história. Posição que leva para b), que uma tentativa prévia de esboço do início da história dos cristãos-novos, e seus estabelecimentos em "Alagoas", não deve ser tratada de maneira linear e genealógica, isto é, que os primeiros cristãos-novos (XVI-XVII) serão, consequentemente, os ancestrais dos que aparecerem no território ainda no XVII, alargando para o XVIII e XIX. Posto isso, têm-se c), que o que será esboçado adiante é o início histórico dos cristãosnovos em "Alagoas Colonial", obedecendo a motivações pessoais e condicionados por questões exteriores. É necessário para indicar aqueles que constituíram descendentes e verificar, com pesquisas futuras, as flutuações de famílias e os aparecimentos de novos personagens ao decorrer dos séculos.

As vilas do sul (hoje Alagoas) eram um espaço da Capitania de Pernambuco, com um litoral utilizado ao cultivo de diversos bens de mercado, subsistência e da cana de açúcar ${ }^{28}$, banhado por rios que poderiam garantir alimentação e dominado pelos neerlandeses durante suas ocupações na Capitania ${ }^{29}$. Não é de se espantar que o território "alagoano" tenha tido investimentos de cristãosnovos. De tal modo, como também se percebem as ramificações de famílias e formações de novas, a existência de crimes julgados pela inquisição e as denúncias feitas. Inclusive, sofreram pela discriminação, como se pode ver nas habilitações para os cargos do Santo Ofício, na admissão aos

\footnotetext{
${ }^{26}$ Nas palavras de Anita Novinsky: "Tudo ainda está por ser estudado na história da Inquisição no Brasil, que atuou do Amazonas ao Rio Grande do Sul. Há estados ainda não pesquisados, completamente virgens, como Alagoas". Cf. NOVINSKY, Anita. Entrevista por Rodrigo Elias. Revista de História da Biblioteca Nacional, Ano 7, n⿳0 73, Outubro de 2011, p. 32.

${ }^{27}$ MOTT, Luiz. A inquisição em Alagoas. Debates de História Regional (Revista do departamento de história da UFAL), n⿳0 1 , Maceió, 1992. MOTT, Luiz. Bígamos de Alagoas nas garras da Inquisição. Revista Ultramares. Maceió: Alagoas, GEAC, № 1, Vol. 1, Janeiro-Julho 2012.

${ }^{28}$ DIÉGUES Jr. Op. Cit., 2006. LINDOSO, Dirceu. A razão quilombola: estudos em torno do conceito quilombola de nação etnográfica. Organizado por Bruno Cézar Cavalcanti. Maceió: EDUFAL, 2011, pp. 29-46.

${ }^{29}$ AZEVEDO, José Ferreira. Formação Sócio-Econômica de Alagoas, o Período Holandês (1630-1654): Uma Mudança de Rumo. In: CAETANO, Antonio Filipe Pereira (org.). Alagoas colonial: construindo economias, tecendo redes de poder e fundando administrações (séculos XVII-XVIII). Recife: Ed. universitária da UFPE, 2012. CURVELO, Arthur. Pescaria e Bem Comum: Pesca e Poder Local em Porto Calvo e Alagoas do Sul (séculos XVII e XVIII). In: CAETANO. Op. Cit., 2012.
} 
ofícios da Câmara Municipal e como irmãos de Confrarias mais afeitas aos estatutos da "pureza de sangue" (como a Ordem Terceira do Carmo da Vila das Alagoas).

Seguindo as pistas e informações de Manuel Diégues Júnior, têm-se alguns empreendimentos no território sul, com a construção dos primeiros engenhos em terras das Alagoas, nos finais do século XVI. Infelizmente, Diégues Júnior não se atentou às origens de cada família (com algumas exceções, mas não infalíveis) e não deu pistas sobre genealogias de cristãos-novos. Citou algumas denúncias ao Santo Ofício, decorrentes da visitação de 1593-1594 em Pernambuco, apenas para comprovar nomes de engenhos e terras, mas causando confusão para saber quem foi o denunciado a cristão-novo30. Já no período holandês em Pernambuco, houve a criação e o funcionamento de uma esnoga na região do Penedo do Rio de São Francisco, indicando uma boa dinâmica acerca das tradições judaicas que foram permitidas pelo governo holandês em seus anos de dominação ${ }^{31}$. E, da mesma maneira, em Porto Calvo, no momento da captura de Calabar, estaria junto a ele o Almoxarife do Forte de Nazaré, o cristão-novo português Manuel de Castro ${ }^{32}$. Tanto Porto Calvo (provavelmente pelo açúcar), quanto Penedo (pelo gado e subsistência), foram espaços onde comerciantes judeus passaram, com vistas a manutenção de seus negócios ${ }^{33}$. Portanto, não se deve pensar a história do cristão-novo apenas pelas suas atitudes religiosas permitidas por Nassau ou perseguidas pela Inquisição, mas, sobretudo, por atitudes socioeconômicas que ajudaram a construir os espaços das Vilas, essenciais para se compreender a aspectos da história de alagoas.

Durante as batalhas da restauração, dez judeus foram aprisionados pelos homens de João Fernandes Vieira no Forte Maurício, perto da Vila de Penedo 34 . José Ferreira Azevedo, se valendo dos relatórios dos holandeses, informa que "nas 'duas alagoas, existem três engenhos de cerca de 400 habitantes; vivem de farinha, tabaco e gado; são na maioria cristãos-novos"'35. Enquanto isso, o genealogista Francisco Antonio Doria sugere que, para o território alagoano, tanto os Lins, os Barros Pimentel (de Porto Calvo e Alagoas), os Acioli e vários ramos da família Holanda, Cavalcante e Paes

\footnotetext{
30 DIÉGUES Jr. Op. Cit., 2006.

31 VAINFAS. Op. Cit., 2010, pp. 105, 148. MELLO, José Antônio Gonsalves de. Gente da Nação: cristãos-novos e judeus em Pernambuco, 1542-1654 - 2a ed. Recife, Fundaj. Editora Massangana, 1996, pp. 229-231.

32 WIZNITZER, Arnold. Os judeus no Brasil Colonial. São Paulo: Livraria Pioneira Editora; Editora da Universidade de São Paulo, 1966, p. 52.

33 VAINFAS. Op. Cit., 2010, pp. 227, 236-237.

34 VAINFAS, Ronaldo. Os prisioneiros do Forte Maurício: redes judaicas e identidade religiosa no contexto da Restauração portuguesa e das guerras pernambucanas no século XVII. In: FRAGOSO, João. Gouvêa, Maria de Fátima (orgs.). Na trama das redes: política e negócios no império português, séculos XVI-XVIII. Rio de Janeiro: Civilização Brasileira, 2010. NOVINSKY. Op. Cit., 2009, p. 87. ISRAEL, Jonathan I. Judeus sefaradim neerlandeses, política milenarista e a luta pelo Brasil (1645-1654). In: SCHWARTZ. MYRUP. Op. Cit., 2009, p. 169-170.

${ }^{35}$ AZEVEDO, José Ferreira. Formação sócio-econômica de Alagoas: O período holandês (1630-1654) - uma mudança de rumo. Tese de Doutorado, FFLCH, Universidade de São Paulo, 2002, p. 51.
} 
Barreto tem descendência das famílias cristãs-novas pernambucanas ${ }^{36}$. Uma ótima pista para decifrar essas genealogias seria o depoimento dado por Isaac de Castro, quando julgado pela Inquisição portuguesa em 1644, denunciou 72 homens (que não contou com as esposas), onde alguns moravam em Porto Calvo e Vila das Alagoas ${ }^{37}$.

Essas seriam as principais pistas (que se tem no momento) para compreender a participação dos cristãos-novos no início das ocupações nos territórios sul da Capitania de Pernambuco. Uma data precisa é praticamente impossível e vai depender da posição do historiador. Se for vista no prisma da ocupação lusa, pode começar já com Cristovão Lins. No âmbito da Inquisição, ficaria no final do XVI e início do XVII. Como um grupo unido, que praticou seus ritos religiosos, só se tem vestígios que tenha acontecido durante o período holandês, sendo difícil verificar, por enquanto, para outros momentos históricos ${ }^{38}$. Observar as continuidades no XVII e XVIII é importante, mas igualmente necessário é, em tempos futuros, verificar as originalidades de recém cristãos-novos chegados em "Alagoas Colonial" no período pós-holandês e no século seguinte.

\section{Inquisição}

Até o presente momento, tem-se para "Alagoas colonial" apenas um caso de cristão-novo preso por "judaizar" (logo, praticava os ensinamentos religiosos da religião de Moisés, o que era condenado pela Inquisição de Portugal) ${ }^{39}$. Levado ao palácio de Estaus e sentenciado à morte na fogueira ${ }^{40}$. Teve seus bens confiscados e a excomunhão maior ${ }^{41}$ no auto de fé de 20 de setembro de 1733 . Era 0 lavrador de mandioca Fernando Henriques Álvares, de 37 anos de idade, natural da Vila de Moura, Évora e morador na Vila de Penedo do Rio de São Francisco, casado com Ana Rodrigues de Figueiredo 42 .

36 DORIA, Francisco Antonio. Sangue Converso no Brasil Colônia, I. Acessível em: http://www.arquivojudaicope.org.br/arquivos/bancodearquivos

37 WIZNITZER. Op. Cit., 1996, p. 104. VAINFAS. Op. Cit., 2010, p. 285-307.

${ }^{38} \mathrm{~A}$ importância de delimitar cristãos-novos enquanto "grupo" ou "indivíduos" é importante. De acordo com Janaína Guimarães, para Pernambuco do século XVI, "As estratégias individuais e familiares superaram uma idéia de grupo, quando os investimentos necessários à manutenção de uma memória coletiva não mais eram realizados, salvo alguns casos (...)", SILVA, Janaína Guimarães da Fonseca e. Modos de pensar, maneiras de viver: Cristãos-novos em Pernambuco no século XVI. Dissertação (mestrado em História), Universidade Federal de Pernambuco, Centro de Filosofia e Ciências Humanas, programa de pós-graduação em História: Recife, 2007, p. 125.

39 SIQUEIRA. Op. Cit., 1978, p. 71. De acordo com Janaína Guimarães Silva, "(...) o criptojudaismo (a manutenção de crenças e práticas judaicas) era característico da comunidade dos cristãos-novos portugueses", SILVA. Op. Cit., 2007, p. 35. ${ }^{40}$ Foi "relaxado ao braço secular", ou seja, "Sentença de morte na fogueira pronunciada pela Igreja, porém executada pelos funcionários da Coroa". NOVINSKY. Op. Cit., 2009, p. 242.

41 "O réu ficava inteiramente separado da Igreja e privado dos sacramentos e quaisquer benefícios eclesiásticos. Se o réu não denunciasse ou confessasse no prazo de trinta dias, segundo o Monitório Geral, incorria em excomunhão maior". NOVINSKY. Op. Cit., 2009, p. 241.

42 NOVINSKY. Op. Cit., 2009, p. 96. ANTT. Tribunal do Santo Ofício, Inquisição de Lisboa, proc. 8172. http://digitarq.dgarq.gov.pt/details?id=2308276 
Destarte como seu pai, era tratante, morava no Engenho de São José e sustentava-se com sua lavra de mandioca e comércio de animais. No confisco de seus bens constavam duas escravas, doze bestas, além de outras dívidas por compra de gado, empréstimos a pessoas, como o do pardo que fazia a passagem do gado para Pernambuco. Todavia, não apenas devia, mas era credor de Bernardo de Souza, "morador no Sertão". Teria ido fixar residência em Penedo após as várias denúncias e prisões de outros cristãos-novos na Paraíba, anos antes ${ }^{43}$.

Tinha aprendido tudo com seu tio Simão Rodrigues, na Paraíba, lavrador de cana de açúcar, que o ensinou a se salvar na lei de Moisés. Instruiu-se nos ritos judaicos e nas orações, com suas tradições e falas, inclusive em castelhano ${ }^{44}$. Durante o interrogatório disse ter nascido católico, aprendendo todos os rituais e orações (que recitou para os Inquisidores). Após ser "iniciado" na religião judaica, começou a negar vários aspectos, mas mantinha várias atividades cristãs de fachada, para não despertar suspeitas na sociedade. Mas mesmo assim, na privacidade de sua casa respeitava os sábados e não os domingos cristãos, fazendo orações com as mãos abertas e tantos outros costumes ${ }^{45}$.

Os Inquisidores, ao final dos interrogatórios, concluíram que Fernando Henriques Álvares tinha características de "malícia, fingimento, diminuição, sendo herege impenitente, apóstata, ficto, falso e simulado". Sua condenação foi a excomunhão maior e a queima na fogueira. "Fernando Henrique Álvares foi sentenciado no Auto de Fé que realizou-se na Igreja de São Domingos de Lisboa, aos 20 de setembro de 1733, estando presente el Rei D. João V, o Príncipe D. José e outros infantes Reais". 0 palco tinha sido armado e o teatro da Inquisição tomou forma quando "59 presos ouviram nesta ocasião suas condenações, a maior parte deles sendo degredados para as galés ou para o Ultramar. Destes, cinco judeus foram queimados"46.

Como maiores perseguidos da Inquisição portuguesa, é quase óbvio que os cargos de agentes do Santo Ofício não fossem abertos aos cristãos-novos. Os rigores da admissão faziam com que, todo pretendente a Familiar ou Comissário, sofresse uma pesquisa minuciosa de sua geração familiar. Os que eram admitidos conseguiam "limpar o sangue" e demonstrar seu poder perante a sociedade, como um homem "cristão-velho, branco, de limpeza, honras e qualidades". Todavia, alguns foram pegos nessa malha e sofreram os ataques do Tribunal47.

\footnotetext{
43 MOTT. Op. Cit., 1992, pp. 22-23.

44 Sobre a questão de "esquecimento", "omissão", "construção de memória", "ensinamentos" para entender e melhor traçar hipóteses das "resistências judaicas" dentro de uma sociedade que era contra, tais práticas, foi importante a leitura de MOTTA, Márcia Maria Menendes. História, memória e tempo presente. In: CARDOSO. VAINFAS. Op. Cit., 2012. Apesar de não estar trabalhando nesse texto com história oral e tempo presente (por motivos que dispensam explicações), algumas colocações foram essenciais para se entender o fluxo das entrevistas do Santo Ofício.

45 MOTT. Op. Cit., 1992, pp. 23-24.

46 MOTT. Op. Cit., 1992, p. 24.

47 RODRIGUES. Op. Cit., 2011, pp. 101-136.
} 
Foi o caso do Capitão José Gomes de Melo, fidalgo da Casa da Majestade, natural e morador da Vila de Porto Calvo. Dizia-se "limpo de sangue de raça de infecta nação" e cristão-velho, apresentando todas as qualidades para servir no cargo de Familiar do Santo Ofício da Inquisição de Lisboa. 0 Comissário Manuel da Costa Ribeiro, escrevendo de Olinda em 25 de julho de 1700, enviava carta para o Tribunal em Portugal, alegando que realmente ambos (o Capitão e sua esposa) eram cristãosvelhos, criados em Porto Calvo pela "mais nobilíssima família". Contudo, corria em segredo que o Capitão José Gomes de Mello tinha "raça de hebreu". Tal segredo foi comprovado por depoimentos de Francisco Berenguer de Andrade e Antônio Muniz de Figueiredo, que destrincharam os casamentos da família e atestavam que ambos, José Gomes de Melo e Jerônima de Almeida (sua esposa), eram primos legítimos e descendentes de Beatriz Mendes, que além de cristã-nova, teve os dois pais castigados pelo Santo Ofício por judaísmo, sendo a mãe queimada na fogueira. Beatriz teria sido adotada e levada para Pernambuco por Dona Beatriz de Albuquerque, mãe do Donatário Duarte Coelho de Albuquerque, inserida nas dinâmicas locais, inclusive se casando com um tal de Arnão de Holanda, flamengo ${ }^{48}$.

Mesmo tendo sido criado nos meios cristãos-velhos, alçado o cargo de Capitão, fidalgo da Casa de Majestade, José Gomes de Melo não escapou da mácula de "sangue hebreu". Era parcialmente aceito pela sociedade, quem sabe por conta do poderio da família ao qual estava ligado e aos possíveis serviços prestados a Monarquia portuguesa. Entretanto, a "pureza de sangue" falava mais alto e a descendência judaica de José Gomes de Melo foi levada ao público a partir de sua própria petição para conseguir o cargo de Familiar do Santo Ofício. Ao invés de "se limpar", acabou "se manchando" e sofrido os revezes da Instituição aliada à Monarquia que ele tanto defendia. E a população? Sendo Capitão e Fidalgo, é interessante observar como seus títulos e seu prestígio não alcançavam a todos na sociedade, que - no limite - despiu José Gomes de Melo de suas qualidades para reforçar seu estigma de "sangue hebreu", e o pior: com antepassados julgados pelo Santo Ofício e queimados na fogueira de um auto-de-fé49.

Em 5 de julho de 1765 era passada pela Inquisição de Lisboa a carta de Familiar do Santo Ofício a José Inácio de Lima, que tinha 28 anos de idade, era Senhor de Engenho "dos Prazeres", tendo escravos e 20 mil cruzados, sem dívida com ninguém ${ }^{50}$. Se dizia natural e morador da Vila de Porto Calvo, casado com Dona Luzia Francisca de Gusmão, natural e batizada na freguesia de São Pedro Gonçalves do Recife de Pernambuco. A união se deu em 10 de fevereiro de 1755, na ocasião ele tinha

\footnotetext{
48 ANTT. Tribunal do Santo Ofício. Conselho Geral. Habilitações Incompletas, doc. 3263.

49 Se ele "omitiu" ou "se esqueceu" dessa "mácula" na época da habilitação, outros personagens sociais manteriam viva a memória de sua família e de seus antepassados.

50 ANTT, TSO, CGSO, Habilitações. José. Maço 103 - doc. 1465.
} 
apenas 19 anos de idade. Sua família já era enraizada nos espaços "porto calvenses", somente seus bisavôs maternos e paternos eram naturais de Portugal.

De acordo com as testemunhas, os avós paternos eram conhecidos como lavradores de Cana de Açúcar, sendo que no ano de 1763 o avô já era falecido. Em Ipojuca, um dos entrevistados ouvira falar que "Fulano da Costa Freitas", não sabendo se era Antonio ou João, era branco, mas havia um rumor de não saber se era cristão-velho, sendo morador no lugar de Utinga, já pertencente a freguesia do Cabo. Nesse caso, como pode ter sido dado o Hábito do Santo Ofício para alguém que tinha em sua família uma "acusação" de cristão-novo?

A resposta se baseia no fator prova concreta, em que rumores podem ter sido documentados, mas não levados a sério pelo Comissário, visto a quantidade de apenas uma pessoa para a informação. Não havia provas cabais. Visto como outras testemunhas faziam questão de expor que não existiam boatos difamatórios sobre a pessoa inquirida e sua família ${ }^{51}$. Contudo, pensa-se que a necessidade de tal ato já era automaticamente cancelada pela própria natureza da inquirição de habilitação para Familiar do Santo Ofício. As próprias testemunhas que falavam bem de José Inácio de Lima seriam as mesmas que, inconscientemente, livrariam seus avós de qualquer crime difamatório e, possivelmente, do cancelamento do hábito de familiar para José Inácio. Portanto, fofocas difamatórias existiram. Por isso, não houve um completo erro de genealogia ou um desleixo do Santo Ofício em relação a essas possíveis acusações, elas apenas foram derrubadas mediante 0 fluxo que as entrevistas tomaram. O nome do habilitando estava, portanto, livre para auferir seu prestígio e limpeza no cargo de Senhor de Engenho e Familiar do Santo Ofício. Tendo carta passada em 5 de julho de 1765.

O Santo Ofício atuava, como se pode ver nos três casos, de maneiras diferenciadas contra os cristãos-novos. No primeiro houve de fato a acusação, todo o aparato repressivo foi posto em ação para extrair do preso sua declaração de ser um "judaizante" e o palco do auto-de-fé e a fogueira foram o destino final. No segundo, em uma clara tentativa de se mostrar um homem fidedigno do Rei católico de Portugal, o fidalgo da Casa Real foi pego pelos exames genealógicos da Inquisição que, em sua atitude de praxe na discriminação e instrumento normatizador não apenas dos costumes, mas da própria sociedade, mantendo rígidas suas hierarquias e diferenciações, atestou a "impureza de sangue" em um súdito que provavelmente nem saberia que era descendente de judeus. Por conta de sua genealogia - e não de sua criação, já que foi adotado quando criança -, José Gomes de Melo teria correndo em suas veias predisposições heréticas e a descendência daqueles que mataram Cristo,

\footnotetext{
51 No início da Inquisição apenas um rumor seria o suficiente para se abrir um processo de denúncia. Entretanto "a possibilidade de abrir processos e de prender acusados a partir de testemunhas singulares é o segundo aspecto que enfraqueceu, sobretudo na segunda metade do século XVII, a posição da Inquisição, dado o desenvolvimento do campo jurídico nesse período", cf. BETHENCOURT. Op. Cit., 1994, p. 298. cf. SIQUEIRA. Op. Cit., 1978, p. 244, 260 e 279-280.
} 
envenenaram poços e disseminaram a peste negra na Europa, de acordo com o imaginário cristão da época. O terceiro caso, quase foi a repetição do segundo; José Inácio de Lima por pouco não consegue angariar o Hábito de Familiar do Santo Ofício, já que uma fofoca em relação a descendência de seu avô foi levantada, mas derrubada de acordo com o fluxo das entrevistas.

Esse último acontecimento serve como estímulo para ratificar a proposta desse ensaio. Enxergar os cristãos-novos em diversas atividades, por vários tipos de recortes documentais e temáticos possíveis. A rigidez na "verdade" das informações torna o caminho perigoso de se seguir, mas não impossível. Seria José Inácio de Lima parte cristão-novo ou não? Nunca se saberá. Todavia, essa desconfiança fazia parte do cotidiano da conquista, sendo requisito para descriminação e perseguição. Não se deve estudar a Inquisição e a perseguição aberta ou velada aos cristãos-novos apenas pelas acusações "comprovadas" e pelas penas impostas. As fofocas, as difamações, as denúncias e desconfianças também deve fazer parte dessa história. Mesmo que em alguns casos não fosse levado a diante, serve para reforçar a mentalidade ${ }^{52}$ estigmatizadora da sociedade "alagoana", advinda da estruturação da sociedade lusa reinol e se reinventando a partir da inserção dos negros africanos e ameríndios. Estruturação essa que afetou os cristãos-novos de várias maneiras.

\section{Escravidão}

Para Stuart Schwartz, "a escravidão e a raça criaram novos critérios de status que permearam a vida social e ideológica da colônia"53. Tal colocação do historiador americano é essencial para observar as inserções e participações dos cristãos-novos dentro da sociedade colonial, uma vez que fizeram parte do circuito mercantil escravista, aliado com a utilização de sua mão-de-obra no modo de produção na América portuguesa. Subalternizaram os escravos e seus descendentes, étnica e religiosamente, absorvendo ações estratificadoras daqueles que tinham desqualificado os próprios cristãos-novos ${ }^{54}$. Ronaldo Vainfas expôs essa problemática dos judeus e cristãos-novos no centro de

\footnotetext{
52 No mais, foi-se utilizado até agora (e continuará durante os tópicos) a expressão "mentalidade". Apesar de um já distanciamento da atual historiografia desse termo por exprimir muitas vezes um sentido geral e como se fosse comum a todos, muitas vezes pensada como se partisse de cima para baixo. 0 seu uso é possível - e até mesmo necessário - nesse trabalho por falta de maior aprofundamento teórico (baseados em pesquisa empírica) para os casos das categorias "alagoanas" em sua complexidade e particularidades. Porém, é deveras importante salientar que tal denominação implica, acima, e antes de tudo, em uma homogeneidade baseada em dominação, parcial de algumas categorias específicas (essas sendo identificadas em pesquisas empíricas), através de coerção e violência. Mas que não excluiria os diversos estratos sociais subalternos que se apropriaram ou divergiram entre si e contra o "dominador". GINZBURG, Carlo. Os andarilhos do bem: feitiçaria e cultos agrários nos séculos XVI e XVII. São Paulo: Companhia das Letras, 1988, p. 16. BARROS, José D’Assunção. 0 campo da história: especialidades e abordagens. Petrópolis, RJ: Vozes, 2009, pp. 39-40.

${ }^{53}$ SCHWARTZ. Op. Cit., 1988, p. 215.

${ }^{54}$ Apesar de não se ter referências para "Alagoas Colonial", vale salientar que houve, na Capitania de Pernambuco relacionamentos (casamentos) entre cristãos novos, mamelucos, negros e ameríndios, bem como denuncias feitas por esses últimos aos primeiros, SILVA. Op. Cit., 2007, pp. 68-75.
} 
Pernambuco, durante o domínio holandês, pois lá mantinham as relações escravistas. Os mercadores judeus estiveram ativos no tráfico de escravos da África para Pernambuco naquele período, sendo grandes negociantes e colaborando com o negócio negreiro internamente e, por conseguinte, do açúcar ${ }^{55}$. Durante o período holandês, foi enfático que os escravos não podiam ser circuncisados, uma vez que "a circuncisão tornava os escravos completamente judeus". E Vainfas retoma: "sobretudo porque os judeus estavam envolvidos até a cabeça com a compra e venda de escravos no Brasil holandês" 56 . Outra posição importante para salientar é a questão da própria "limpeza de sangue", mas isso ficará para o próximo tópico.

Um caso desse relacionamento com a escravidão pode ser visto em uma denúncia, feita em 1708 por uma negra escrava de nome Tecla[?] e um mulato chamado Ludovico. A reclamação era por conta de maus-tratos que o Senhor de Engenho, Capitão Manoel de Mello Falcão e sua esposa, Anna Maneli, "terceira neta de Branca Dias" 57 , tinham em relação aos escravos. De acordo com as denúncias, o Capitão tinha raiva de um negro, pertencente a Antonio Fariaz[?], que fez questão de comprá-lo para, em uma Sexta Feira da Paixão, açoitá-lo de uma maneira "que só os judeus os fariam em tal dia", tendo depois cortado suas orelhas e dado-as a um cão. Colocação parecida com a que fizeram de Gonçalo Novo de Lira (o segundo), em Pernambuco, tratado como "sumamente rigoroso com os escravos', o que persuadia muita gente de que 'este homem tão mau deve ser judeu"'58. A sua esposa, de "tão mal cristã", prendeu um escravo em uma corrente e o tinha mandado ingerir "um caldo quente fervendo", enquanto uma mulata deveria açoitá-lo até fazê-lo "expirar", sem confissão e sem sacramento. Era conhecido o casal por enterrar seus escravos em buraco nos campos, sem mortalha, encomendas ou qualquer ritual cristão59.

Mas tais denúncias não eram o suficiente. Era necessário jogar com os indícios que o Santo Ofício trabalhava. Nesse caso, ambos os denunciadores tentaram ao máximo ligar as atividades dos senhores com ações judaicas. Somava à denúncia que o Capitão teria, em um de seus dias de fúria, jogado fora de sua casa as imagens de Cristo e da "mãe santíssima", além de tocado fogo em uma imagem de Jesus Cristo. Sua esposa, por conseguinte, tinha uma imagem de Cristo em Marfim que

55 VAINFAS. Op. Cit., 2010, p. 143-144, 154, 158 e seguintes.

56 VAINFAS. Op. Cit., 2010, p. 169.

${ }^{57}$ Famosa Cristã-nova, residente na sesmaria de Camaragibe, Olinda, no século XVI. Casou-se com outro Cristão-novo, Diogo Fernandes. Enviuvou e morreu entre 1579 e 1581. Durante a visitação de Pernambuco, em 1593, o visitador recebeu denúncias sobre os filhos da cristã-nova, por conta de seus trabalhos "judaizantes" que fazia e ensinava em sua sesmaria, inclusive tido mantido ali "uma espécie de Sinagoga bastante ativa durante toda a década de 1560". HERMANN, Jacqueline. Branca Dias. In: VAINFAS. Op. Cit., 2001, pp. 79-80. WIZNITZER. Op. Cit., 1966, pp. 20-22.

${ }^{58}$ MELLO, Evaldo Cabral de. O nome e o sangue: Uma parábola familiar no Pernambuco colonial. $2^{\mathrm{a}}$ edição revista. - Rio de Janeiro: Topbooks, 2000, p. 147.

${ }^{59}$ ANTT. Tribunal do Santo Ofício. Inquisição de Lisboa, Caderno do Promotor, livro 324, fls. 115-115v. Retirados de http://digitarq.dgarq.gov.pt/. Agradeço a professora Márcia Eliane de Souza e Mello da Universidade Federal do Amazonas por ter me entregue os downloads dos fólios digitalizados e a referência completa. A leitura e interpretação são de inteira responsabilidade minha. 
deixava guardada em uma Câmara, sem oratório, e um dia por semana se trancava e não permitia que ninguém lá entrasse. O Familiar do Santo Ofício, Antonio de Araújo Barbosa ${ }^{60}$, encarregado da inquirição já derramava o preconceito em suas tintas, dizendo que "deste mal tronco [Branca Dias] é produzida esta árvore [a esposa do Capitão], não pode deixar de reinar o mal sangue". Ou seja, todo cuidado era pouco e o castigo e a perseguição deveriam ser em boa quantidade. Ter ligado ambos como "primos de segundo grau", só reforçaria a endogamia judaica, as "predisposições" heréticas contra Jesus Cristo, a tortura e a falta de consideração católica com os escravos.

Apesar de a denúncia ter tido respaldo, continua sendo uma denúncia, sem um fim concreto (por enquanto). Por isso, é demasiado arriscado já chamar o casal de senhores de engenho de "judeus" ou "cristãos-novos". Por outro lado, essa denúncia alerta para dois pontos: a) usando um termo de Antonio Caetano, tal documento serve para "medir o termômetro social"61 dos espaços. Neles, os escravos tinham noções de resistência que perpassavam por várias estratégias, inclusive sobre a religião judaica, fossem falas verdadeiras ou enviesadas e confusas; b) se o casal for realmente de "judaizantes", estar-se-á perante um Capitão Senhor de Engenho, logo, homem estabilizado na sociedade, casado, rico e de posses, que matava escravos como se fossem pernilongos, dando a impressão que tinha cabedal para repor seus cativos, o que não deixa de ter uma dose de exagero; e c) se todos esses indícios ditos pelo Familiar do Santo Ofício forem verídicos, ver-se-á não - ainda ritos judaicos em ação, como criptojudaísmo (apesar do Familiar dizer que eles são judeus e merecem excomunhão), mas ações de resistência às imposições do catolicismo, mesmo que suas frustrações tenham sido descontadas nos negros e nos escravos; inclusive praticados mais pela esposa, dando margem à interpretação do judaísmo feito pelas mulheres ${ }^{62}$.

Esse é o único exemplo que se tem notícia até agora (em pesquisas) sobre relação dos negros, mulatos e escravos em relação aos seus senhores e acusações de atividades possivelmente judaicas, apesar de parecerem mais "anticristãs" do que propriamente de rituais criptojudaicos. Mesmo sendo uma denúncia, contribui para complexificar essa sociedade "alagoana". Ao tentar desvendar os caminhos percorridos pelos cristãos-novos na sua inserção, na dinâmica local, percebe-se que segue muitos dos costumes lusos daqueles que os perseguiam; como dos próprios escravos, que tinham noção desses costumes religiosos e souberam utilizá-los contra seus senhores ${ }^{63}$. Da mesma forma, tal

\footnotetext{
60 MACHADO. Op. Cit., 2013, pp. 352-353.

61 CAETANO, Antonio. "Por ser público, notório e ouvir dizer...": Queixas e súplicas de uma conquista colonial contra seu Ouvidor (Vila de Penedo, 1722). In: CAETANO, Antonio Filipe Pereira (org.). Alagoas Colonial: Construindo Economias, Tecendo Redes de Poder e Fundando Administrações (Séculos XVII-XVIII). Recife: Editora Universitária UFPE, 2012, p. 153.

62 ASSIS. Op. Cit., 2006. ASSIS, Angelo Adriano Faria de. Espelhos de Esther. As mulheres e a resistência criptojudaica no mundo colonial. In: ALMEIDA. SILVA. RIBEIRO (orgs.). Op. Cit., 2012.

${ }^{63} \mathrm{Em}$ um âmbito geral, Luiz Mott escreveu que "diversos amos e senhores foram denunciados ao Santo Oficio por seus escravos, sobretudo por sodomia e judaísmo". Cf. Cotidiano e vivência religiosa: entre a capela e o calundu. In: MELLO E
} 
caso ajuda a interligar os três temas, pois perpassa o preconceito e a perseguição aos judeus (depoimento do Familiar), a força da instituição da escravidão (os depoimentos dos escravos) e os costumes lusos (endogamia e tentativa de adentrar na sociedade, mesmo que seja de caráter exterior).

\section{Costumes lusos}

A endogamia era um fator forte dentro da cultura judaica, principalmente a sefardita ibérica ${ }^{64}$. Contudo, não foram raros os casos de cristãos-novos que casaram-se com cristãos-velhos ${ }^{65}$. Ao contrário, poderia até mesmo ser visto como algo inevitável ou "racionalmente pensado", fazendo com que a exogamia entre cristãos-velhos e cristãos-novos reforçassem as características de nobreza e linhagem "pura" daqueles que se gabavam de serem cristãos-velhos puros ${ }^{66}$. É importante salientar que em diversos casos houve rejeição, impedimentos e barreiras no ponto de vista do cristão-velho adquirir matrimônio com uma cristã-nova (e vice-versa) ${ }^{67}$. Na contramão, como bem observou Evaldo Cabral de Mello para Pernambuco colonial, utilizando do caso de Branca Dias, "(...) ao menos de uma parte da comunidade marrana em Portugal e no Brasil, a estratégia matrimonial da família privilegiava 0 casamento com cristãos-velhos e os desestimulava com os cristãos-novos". Essa opção poderia ser vista nos dotes, em que "(...) a filha que se consorciava endogamicamente perdia o direito ao dote que, em compensação, era aliciantemente concedido à filha que se aliava exogamicamente". Essa atitude, vista no caso da família de Branca Dias, "(...) constitui um desmentido formal à teoria propagada pelo anti-semitismo na época segundo a qual o cristão-novo só casava exogamicamente no fito de converter o cônjuge cristão-velho à religião de Moisés". Daí poder ser visto nesses arranjos matrimoniais um misto conflituoso "(...) entre a fidelidade religiosa e a ambição social"68. Porém, no decorrer do tempo e do espaço, os ideais de pureza de sangue eram estritamente fortes dentro dessa sociedade lusobrasileira.

SOUZA, Laura de (org.). História da vida privada no brasil: Cotidiano e vida privada na América portuguesa, vol. I. NOVAIS, Fernando. (dir.). São Paulo: Companhia das Letras, 1997, p. 202. Do mesmo modo, "os cristãos-novos podiam ser denunciados por qualquer pessoa, nomeadamente pelos seus escravos", cf. BETHENCOURT. Op. Cit., 1994, p. 300.

64 "Mas a Zur Israel (...) assumiu postura francamente contrária à miscigenação, apegada à endogamia radical", cf. VAINFAS. Op. Cit., 2010, p. 151, 169. A relação da genealogia própria dos judeus e conversos se encontra em REGO. Op. Cit., 2009, pp. 452-456.

65 BOXER. Op. Cit., 2002, p. 279. SCHWARTZ. Op. Cit., 1988, p. 226.

66 STUDNICKI-GIZBERT, Daviken. A Nação e o Império: o espaço da diáspora marítima portuguesa no Atlântico LusoIbérico do século 17. In: SCHWARTZ. MYRUP. Op. Cit., 2009, 126-127.

$67 \mathrm{Um}$ caso de um comerciante queria impedir de seu filho casar-se com uma descendente de cristãos-novos foi bem retratado por SOUZA, George Félix Cabral de. Tratos \& mofatras: o grupo mercantil do Recife colonial (c. 1654-c. 1759). Recife: Ed. Universitária da UFPE, 2012, p. 267-281, em especial 275. SCHWARTZ. Op. Cit., 1988, p. 231.

68 MELLO, Evaldo Cabral de. O nome e o sangue: Uma parábola familiar no Pernambuco colonial. $2^{a}$ edição revista. - Rio de Janeiro: Topbooks, 2000, p. 93. A mesma proposta, principalmente para o século XVI até o início da ocupação holandesa, é dada por SILVA. Op. Cit., 2007, pp. 62-63. 
Seguindo as pistas de Ronaldo Vainfas, têm-se esses "costumes lusos" da pureza de sangue também impregnados nos cristãos-novos e judeus, tanto no período da dominação holandesa em Pernambuco, como após tal conjuntura. Durante o domínio holandês, quando a comunidade judaica ganhou mais espaço nas dinâmicas sociais, "foram excluídos os negros, pois o regulamento proibia a circuncisão de escravos"69. Somam-se as proibições dos casamentos entre as mulheres judias com homens mulatos e até mesmo cristãos católicos, voltando a reforçar a endogamia. O próprio Vainfas trouxe a lume a "conversão" de pessoas mulatas à religião de Moisés, contudo, imagina-se sua participação como mínima. O preconceito era sofrido e existiam afastamentos dessas pessoas dentro dos quadros mais internos das sinagogas e da comunidade judaica. No rol dos casamentos, houve algumas situações dos mulatos cristãos-novos e mulatos cristãos-velhos convertidos ao judaísmo se casaram com moças judias, sendo poucas as evidências ${ }^{70}$.

Ou seja, predominou o afastamento das pessoas miscigenadas dos espaços das sinagogas e da dinâmica judaica, principalmente os negros. "E nesse ponto, os judeus eram mais portugueses do que nunca"71. No âmbito dos adágios ladinos, um é de caráter interessante: "Mas negra que Hana, su ermana". De acordo com Vainfas, "era outra maneira de hostilizar mulheres, além de externar o sentido negativo da cor negra"72. Essa cultura "mais portuguesa do que nunca" deve ser alargada. Afinal, uma vez na América, mesmo a dominada pelos holandeses, os lusos já estariam inseridos dentro de uma conquista lusitana, da justificação da escravidão e do comércio negreiro. O preconceito e a estigmatização das "raças infectas" poderia ter ganhado novos reforços com a escravidão. Enfim, pode-se enxergar que houve um choque nas relações culturais, pois a endogamia dos judeus não era uma condição inquebrável e inabalável. Muitas vezes sendo levadas à risca, mas em outros momentos tendo sido reforçado um comportamento contrário ao costume do casamento endogâmico. Mas, não alheio a tudo isso, o casamento (ver adiante), tinha, entre muitas motivações, a cor e a miscigenação como condições sine qua non de estratégias matrimoniais. Portanto, os cristãos-novos teriam se tornado mais luso-brasileiros do que nunca.

No período pós-holandês, tanto em Pernambuco como no restante do território da América portuguesa, os ideais de "pureza de sangue" em relação aos negros e ameríndios continuou sendo um fator preponderante na formação das categorias sociais locais e na manutenção da escravidão ${ }^{73}$. Havia

69 VAINFAS. Op. Cit., 2010, p. 151. "O problema não residia na condição escrava, mas na cor negra ou origem africana. É certo que tal exclusão também se aplicava aos mulatos".

70 VAINFAS. Op. Cit., 2010, pp. 151, 169-170.

71 VAINFAS. Op. Cit., 2010, p. 169.

72 VAINFAS. Op. Cit., 2010, p. 185.

730 autor, contudo, diferencia "preconceito racial" de "preconceito de cor". Sendo o primeiro existente desde Portugal continental (Judeus e Mouros) e o segundo criado e reformulado de acordo com as vicissitudes da colonização americana. VAINFAS, Ronaldo. Moralidades brasílicas: deleites sexuais e linguagem erótica na sociedade escravista. In: SOUZA, Laura de Mello e (org.). História da vida privada no Brasil: cotidiano e vida privada na América portuguesa. / Coordenador geral da 
casos de cristãos-velhos decidirem casar-se com cristãs-novas pelo fato delas serem brancas (e poderem esconder sua descendência) ao invés de arriscar o matrimônio com negras e mulatas ${ }^{74}$.

Todavia, não pode o pesquisador se perder nessas estratégias como se 0 cristão-novo fosse mais bem aceito. Os preconceitos raciais aos cristãos-novos continuaram fortes durante os séculos XVII e XVIII. De acordo com Lina Gorenstein, "Para o Santo Ofício, os cristãos-novos mantinham religião judaica em segredo. Sempre foram considerados suspeitos de heresia porque, de acordo com o preconceito, o judaísmo fora incorporado pelo leite materno, não pela escola, pelos livros ou pela tradição"75. As rejeições em cargos e espaços institucionais religiosos são uma prova ímpar, para se apreender como a sociedade luso-brasileira tentava, de várias maneiras, criar uma "nobreza da terra" que se igualasse ao máximo da Reinol ${ }^{76}$. Coloco mais dois espaços de poder e sociabilidade - para "Alagoas" - em que os descendentes de cristãos-novos não deveriam ter (mas podem ter conseguido) vez nem voz.

Desde seus primeiros contornos políticos, o território sul de Pernambuco pode ser estabelecido como um ambiente de inserção de "cristãos-novos" e, ao mesmo tempo, excludente com seus descendentes. Arthur Curvelo demonstrou que as três povoações (Porto Calvo, Alagoas e Penedo) podem ter recebido seu estatuto de Vila exatamente como meio de defesa à ameaça holandesa ${ }^{77}$. Uma vez já "dominada", pelo menos a Vila das Alagoas recebeu a Câmara dos Escabinos ${ }^{78}$, logo depois se tornando Câmara da Vila das Alagoas após a expulsão dos batavos. Em conjunção a ela, houve a de Porto Calvo e de Penedo.

O que se atenta é quem estava compondo a Câmara. Pode-se imaginar que "Alagoas" recebeu contribuição de cristãos-novos em sua formação, e maior mobilidade durante o período holandês. Após a restauração, os ideais de pureza de sangue e o relativo preconceito racial voltaram à tona nas instituições lusas. Seguindo o caso de José Gomes de Melo79, se tem esses cristãos-novos se relacionando com a coletividade, visto seus serviços, ao que seria o "bem-comum" da sociedade.

coleção Fernando A. Novais. São Paulo: Companhia das Letras, 1997, pp. 238-239. SCHWARTZ. Op. Cit., 1988, pp. 209215.

74 VAIFAS. Op. Cit., 1997, p. 239.

${ }^{75}$ GORENSTEIN, Lina. Ter origem judaica era sinônimo de culpa?. In: Revista de História da Biblioteca Nacional: Dossiê Inquisição. Ano 7, nº 73, Outubro de 2011, p. 25.

${ }^{76}$ Ou seja, era uma qualidade autoproclamada, pois desejavam se mostrar e comportarem como "nobres". Importante salientar que a "pureza de sangue" era uma condição utilizada para alguém se comportar e se demonstrar "nobre", por não tem em sua família alguém ligado à descendência moura, judaica e africana. SILVA, Maria Beatriz Nizza da. Ser nobre na Colônia. São Paulo: Editora da UNESP, 2005. Para o período ante-bellum de Pernambuco Colonial, conferir a síntese de MELLO, Evaldo Cabral de. Persistência dos modelos reinóis (2). In: MELLO, Evaldo Cabral de. Um imenso Portugal: História e historiografia. - São Paulo: Editora 34, 2002, pp. 80-91. BOXER. Op. Cit., 2002, p. 282.

77 CURVELO, Arthur. O senado da câmara de Alagoas do Sul: Governança e Poder Local no Sul de Pernambuco (16541732). Dissertação de Mestrado. Universidade Federal de Pernambuco (UFPE), Programa de pós-graduação em História. Recife, 2014, p. 52.

78 VAINFAS. Op. Cit., 2014, p. 247. CURVELO. Op. Cit., 2014, p. 56-60.

79 O Capitão, fidalgo da Casa da Majestade, natural e morador da Vila de Porto Calvo, que "se descobriu" cristão-novo em um pedido de habilitação para ser Familiar do Santo Ofício. Segundo "caso" estudado no tópico "Inquisição". 
Todavia, muitas portas estariam fechadas, como a do mundo da política institucionalizada das Câmaras Municipais.

Proibia-se em seus quadros a admissão de pessoas de "raça de infecta nação", o que, na teoria, faz-se conjecturar que os cristãos-novos não tinham vez nos atos da municipalidade. Isso na teoria. $\mathrm{Na}$ prática, em vários rincões do império marítimo português, diversas vezes essas imposições foram ignoradas. Mas, convém salientar, Boxer encontrou essas rachaduras para os indivíduos mulatos e/ou descendentes de negros, ameríndios, hindus e populações locais da África, Goa e Macau. Ao que tudo indica, em relação ao cristão-novo, desde 1633 que as Câmaras do território da América portuguesa foram intransigentes com as participações dos descendentes de judeus convertidos ${ }^{80}$. Esse estatuto reforçava o ideal de pureza de sangue e servia com mecanismo de poder na hora de hierarquizar a sociedade e estabelecer, em seus determinados contextos históricos, as específicas categorias que visavam monopolizar algum tipo de poder ${ }^{81}$.

Outro espaço eram as Confrarias religiosas. Como as Câmaras, estas foram disseminadas por todo o espaço do Império português. No caso de Alagoas, a Ordem Terceira do Carmo tem papel relevante nesse estudo sobre os costumes lusos acerca da "pureza de sangue". Já se viu que os cristãos-novos poderiam ser pessoas que caminhariam pelos espaços das categorias dominantes e mandonistas ou eram pequenos oficiais, vivendo sua vida nas conquistas ${ }^{82}$. Ora, fazer parte de uma Confraria de peso era sinônimo de nobilitação, criação e manutenção de um status que indicasse superioridade frente a outros grupos, estratos e desafetos particulares da sociedade. Instaurada (a partir do Livro de Atas) em 1748, "tresladadas da Nossa Ordem $3^{a}$ do Carmo da Bahia", já era enfática em seus quadros aos Irmãos e Irmãs que desejassem aderir à Ordem. Deveriam ser "limpo de sangue sem raça de Judeu, Mouro, Mulato, ou de outra qualquer nação". Livre também eram para estar de qualquer infâmia, crime e condenação de justiça eclesiástica ou secular. Soma-se a isso tudo que em hipótese alguma era pessoa bem-vinda quem exercesse algum ofício vil (mecânico) ${ }^{83}$.

Essa insistência costumeira atingiu, por conseguinte, não apenas as ingressões dos cristãosnovos nas instituições, mas o próprio preconceito e perseguição dado por agentes de justiça em seus ofícios. Um caso exemplar foi o do Ouvidor João Vilela do Amaral, que em correição na Vila de Porto

\footnotetext{
80 MAGALHÃES, Joaquim Romero. Concelhos e organização municipal na Época Moderna: Miunças 1. - Coimbra: Impressa da Universidade de Coimbra, 2011, p. 28. BOXER. Op. Cit., 2002, p. 290, 294-295. BETHENCOURT, Francisco. Configurações políticas e poderes locais. In: BETHENCOURT. CURTO. Op. Cit., 2010, p. 230.

81 Para o Rio de Janeiro, houve embates entre a aristocracia agrária e os mercadores, vulgarmente incriminados como "judeus" (que também queriam participar dos cargos municipais). "A poderosa pressão exercida pelos mercadores sobre a antiga oligarquia local no fim do século XVII e princípio do XVIII poderá ter contribuído para a violenta repressão por parte da Inquisição, entre 1707 e 1714, quando cerca de 130 cristãos-novos acusados de serem judeus foram enviados para Lisboa para julgamento". BETHENCOURT. Op. Cit., p. 257.

82 BOXER. Op. Cit., 2002, p. 282.

83 Instituto Histórico e Geográfico Alagoano. Secção de Documentos. 00031-01-03-11, Ordem $3^{a}$ de Nossa Senhora do Monte do Carmo. Livro de atas. Vila da Alagoas do Sul, 05 Dez, 1728, fl. 14-16v.
} 
Calvo, entrou em desavenças contra a população local, sendo rechaçado por conta de seus "despotismos". Em sua defesa, alegava que a Vila de Porto Calvo estava cheia de "infinitos" religiosos cristãos-novos, leprosos, condenados a morte de forca por sentença da Relação [da Bahia] e iletrados, não sabendo a gramática ${ }^{84}$. Não é de se espantar que um de seus parceiros era justamente o Padre Domingos de Araújo Lima, clérigo secular, senhor de engenho e Comissário do Santo Ofício ${ }^{85}$. Não se tem notícia de alguma denúncia ou processo envolvendo cristão-novo naquele momento histórico, mas tal acontecimento já serve para imaginar tanto a possível permanência de famílias cristãs-novas em Porto Calvo, como o preconceito bem enraizado no agente régio, onde "cristão-novo" e "leproso" poderia ter sido um xingamento intempestivo, sem provas concretas, mas que fazia parte do cotidiano $^{86}$. Soma-se 0 fato da denúncia ser direcionada aos clérigos de Porto Calvo, ou seja, encontram-se agora alguns indícios dessa participação dos cristãos-novos nos espaços religiosos, aos quais estavam completamente impedidos de exercer o ofício, podendo subverter o sistema ${ }^{87}$.

Ao que parece não se pode afirmar essa relação dos cristãos-novos com o clero em Porto Calvo, mas, ao que tudo indica, "o defeito de sangue seria, aliás, 'muito vulgar' em Olinda, entenda-se, entre 0 clero da cidade" 88 . Podendo essa acusação tanto ser um ato intempestivo do Ouvidor como uma possibilidade ínfima de ser verdade não para todo um clero, mas uma parcela dele, sendo um ótimo indício para futuras investigações. Como hipótese prévia, pode-se pensar que a ausência de "porto calvenses" às habilitações do Santo Ofício, entre 1706-1765, pode ser um indicativo dessas possíveis "manchas de sangue". Afinal, o primeiro Familiar do Santo Ofício em Porto Calvo era um Senhor de Engenho natural do Reino, mas o segundo era natural de Porto Calvo. Esse último (e aí está o indício) é quem sofreu as fofocas nas inquirições de pessoas que não sabiam se seus entes familiares mais velhos eram parentes de pardos e cristãos-novos ${ }^{89}$. Uma pesquisa prosopográfica sobre os Senhores de Engenho, na região da Vila de Porto Calvo poderia oferecer subsídios melhores para se saber uma possível porcentagem de quem poderia ter relações com cristãos-novos no seio da família.

\footnotetext{
84 AHU. Alagoas Avulsos. Doc. 21, fl. 34v, 37v-38.

85 Nos seus estudos sobre os bígamos, Luiz Mott afirmou que "no caso de Alagoas, patenteia-se a participação da justiça civil na captura e prisão dos bígamos, demonstrando íntima colaboração entre a cruz e a espada". Cf. MOTT, Luiz. Bígamos de Alagoas nas garras da Inquisição. Revista Ultramares. Maceió: Alagoas, GEAC, No 1, Vol. 1, Janeiro-Julho 2012, pp. 40. O Regimento dos Ouvidores da Comarca das Alagoas era copiado do Regimento dos Ouvidores da Capitania de Pernambuco. Entre suas atribuições, uma é de interesse: Todo Ouvidor deveria ser Juiz do Fisco Real e dos Confiscados pelo Santo Ofício, e Conservador dos Familiares do Santo Ofício, cf. Informação Geral da Capitania de Pernambuco. In: Anais da Biblioteca Nacional do Rio de Janeiro. Rio de Janeiro: Biblioteca Nacional, Volume XXVIII, 1906, p. 459.

86 De acordo com o Alvará de 12 de setembro de 1564, relativo às proposições do Conselho Tridentino, era cabível o apoio do "braço secular" nos assuntos que envolvessem questões inquisitoriais, cf. Ordenações Filipinas: livro II e III. Lisboa: Fundação Calouste Gulbenkian, 1985, p. 505-506. Segundo Livro das Ordenações Filipinas. Título VI: "Como se cumprirão os mandados dos Inquisidores". In: Idem, 1985, p. 426.

87 SALVADOR. Op. Cit., 1969.

88 MELLO. Op. Cit., 2000, p. 55.

89 Como visto no caso de José Inácio de Lima, no tópico "Inquisição".
} 


\title{
Pesquisando os cristãos-novos: complexificar a sociedade "alagoana".
}

\author{
Encerro essas linhas com uma instigação de Anita Novinsky:
}

\begin{abstract}
As possibilidades que as fontes inquisitoriais oferecem ao historiador são infinitas. As vidas são entrelaçadas, os negócios são feitos na base da confiança, as redes internacionais se ramificam e a vida dos réus permanece um eterno enigma. Os resultados das pesquisas são imprevisiveis e a vida do réu é um suspense, que cada leitor desvenda como um puzzle90.
\end{abstract}

O que se põem a provocar é: até que ponto tais estatutos foram determinantes? Foram seguidos à risca e levados completamente a sério nesses espaços? Ou, teriam esses súditos lusos ao máximo tentado esconder suas "manchas", casando-se com cristãos/ãs-velhos/as, adentrando em espaços militares reservados a "homens nobres", como vereadores de alguma Câmara Municipal e, até mesmo, burlando os exames de admissão das Confrarias religiosas, que não tinham o mesmo rigor de uma Inquisição?

Dentre esses, quais tentaram se manter cristãos-velhos, adotando a religião católica e recebendo os preconceitos da pureza de sangue? Quantos mantiveram as aparências externas de católicos e de cristãos-novos judaizantes "portas adentro" 91? "Qual o legado que os marranos - com sua mentalidade, religiosa ou não, com seus costumes, ritos e ideias - deixaram à civilização brasileira?"92.

No outro lado da moeda, qual a contribuição (ou, nesse caso, a patologia) da Inquisição para essa mesma sociedade ${ }^{93}$ ? Seriam os cristãos-novos realmente conhecidos por todo um espaço? Sofreram suas segregações, infâmias e estigmas por conta de sua descendência? Essas

\footnotetext{
90 NOVINSKY. Op. Cit., 2009, p. 18.

91 SALVADOR. Op. Cit., 1969, p. XXI.

${ }^{22}$ NOVINSKY. Op. Cit., 2009, p. 28. NOVINSKY, Anita. A sobrevivência dos judeus na visão de Baruch Spinoza: o exemplo da Paraíba. In: VAINFAS. FEITLER. LAGE. Op. Cit., 2006, p. 153. Um ótimo exemplo é da possível influência judaica no XVII, nas obras do Padre Antonio Vieira e nas crenças milenaristas, inclusive de Pedro de Rates Henequim, ROMEIRO, Adriana. Um visionário na corte de D. João V: revolta e milenarismo nas Minas Gerais. - Belo Horizonte: Ed. UFMG, 2001, pp. 99-137 (capítulo III, "o novo mundo entre o milênio e a redenção").

${ }^{93}$ Em termos do "direito" e da "procura da verdade", conferir o excelente texto de LIMA, Roberto Kant de. Tradição inquisitorial no Brasil contemporâneo: a incessante busca da "verdade rea"l. In: VAINFAS. FEITLER. LAGE (org.). Op. Cit., 2006. ROMANELLI, Cristina. Fogo que arde sem se ver. In: Revista de História da Biblioteca Nacional: Dossiê Inquisição. Ano 7, $n^{\circ}$ 73, Outubro de 2011, pp. 17-19. De acordo com Anita Novinsky, "em fins do século XIX e princípios do XX, ainda se buscava em Portugal as provas de 'limpeza de sangue' para permitir os portugueses de participar dos quadros da Igreja", cf. NOVINSKY, Anita. Prefácio. In: CARNEIRO. Op. Cit., 2005, p. XX. Carneiro será mais enfática: "Nossos jovens continuam desconhecendo as raízes de nosso pensamento intolerante e raros são aqueles que aprenderam que os cristãos-novos foram perseguidos pelo Tribunal do Santo Ofício. São ainda raras as escolas que incluíram o tema 'racismo' em seus programas de ensino", CARNEIRO, Maria. Nota à terceira edição. In: CARNEIRO. Op. Cit., 2005, p. XIV.
} 
(re)afirmações foram constantes? Em que tempo e determinado acontecimento histórico94? Dividindo esse lado da moeda, qual foi a influência e a força da instituição da escravidão, da pureza de sangue e da mestiçagem em relação à exclusão e estigmatização de "raça", mentalidade desenvolvida e reafirmada em vários momentos da sociedade?

Por isso, como bem disse Studnicki-Gizbert, proponho "expandir e tornar mais complexa a explicação, fazendo com que o resultado se torne menos organizado, porém mais rico"95. Encontrar um lavrador de mandioca preso e levado à fogueira, com confiscos de todos seus bens e excomunhão maior, amaldiçoando-o e a seus descendentes por toda eternidade só nos mostra o quão violenta poderia ser uma sociedade. Do mesmo modo, supostos judeu e esposa judia terem torturado escravos a seu bel-prazer não nos faz pensar sobre a reprodução costumeira das instituições e costumes mais latentes naquele período histórico?

Um caos a priori, sendo derrubado diante das análises. A pesquisa acerca da contribuição social dos cristãos-novos em terras "alagoanas" tem que ser feita a partir da pluralidade de análises e propostas de pesquisas, obedecendo, é claro, o que poderia ser uma "ética do ofício do historiador". Não se pretende cair nos delírios pós-modernos de abrandar as perseguições e a ação inquisitorial ${ }^{96}$. Ou, até mesmo a tentativa de demonizar a imagem do judeu e do cristão-novo como um escravista, tão racista quanto o cristão-velho. Uma vez que nem tudo na história vai como nós queremos, mas quando esticamos o escopo de apreciação, temos um quadro de análise muito melhor, que busca evitar vulgarizações e charlatanismos.

As dificuldades documentais para Alagoas se mostram, à primeira vista, colossais (tem-se apenas um processo). Desse silêncio e resistência, a procura e objetivo de tornar cognoscivel esse mundo subterrâneo, só faria com que a sociedade alagoana e sua história ganhassem com os resultados que podem ser obtidos. Encontrar possíveis respostas e pistas de provas é uma tarefa que deve perpassar por pesquisas empíricas de peso sobre pessoas particulares, famílias, denúncias para inquisição e ligação de pontos comprováveis entre os homens e mulheres estudados e sua possivel descendência cristã-nova. Para isso, me valho da advertência de Paulo Valadares:

Mas como encontrar os sobrenomes utilizados pelos cristãos-novos e seus descendentes se eles desapareceram na população geral? Convém consultar a documentação produzida pela Inquisição (...). É impossivel descobrir a origem de um lusodescendente só pelo nome de família (...). Não há sobrenome cristão-novo, mas um sobrenome ibérico usado por cristãos-

\footnotetext{
94 Sobre "o acontecimento histórico", conferir a lição de BURKE, Peter. A história dos acontecimentos e o renascimento da narrativa. In: BURKE, Peter. (org.) A escrita da história. Novas perspectivas. São Paulo: Editora Unesp, 2011.

95 STUDNICKI-GIZBERT. Op. Cit., 2009, p. 132.

${ }^{96}$ Frutos de uma "perversidade ideológica que pode assumir a prática revisionista em historia". BETHENCOURT. Op. Cit., 2012, pp. 147, 150-151.
} 
novos, que muitas vezes foi o mesmo usado também por cristãos-velhos, ciganos, mouriscos, indígenas... ${ }^{97}$.

Atentar a seus nomes e possíveis vestígios que possam ser achados e entrecruzados nas fontes é o que parece ser o primeiro passo a se dar em "Alagoas Colonial"98. Isso quando se pensa na procura de reconstituir (com deficiências, das quais o historiador não está imune) as árvores genealógicas das famílias cristãs-novas para melhor inseri-las, ou compreender, os acontecimentos nas conquistas. Entretanto, como foi bem explicitado nesse ensaio, a documentação da época colonial é mais rica do que parece. Apesar da documentação da Inquisição ser a comumente utilizada para encontrar tais personagens, tal atitude não descartaria (como tentei constatar) os discursos em que expressões de estigmatização e preconceito aos cristãos-novos eram produzidos. Como uma cultura complexa e rica (a judaica), bem como uma sociedade intricada nas suas relações sociais e mecanismos de poder (a luso-brasileira), inseridas em um espaço onde se existem lacunas enormes de estudos de acontecimentos históricos ("Alagoas Colonial"), torna-se necessário, além dos nomes, as avaliações das ações dos homens em circuitos sociais de poder, para assim verificar o mais próximo possível do peso das atitudes criptojudaicas e das atividades de cristãos-novos "católicos" 99 em "Alagoas Colonial".

\section{Principais referências documentais e bibliográficas}

Arquivo Histórico Ultramarino. Alagoas Avulsos. Documento 21.

ANTT. Tribunal do Santo Ofício. Inquisição de Lisboa. Processos. Processo 8172.

ANTT. Tribunal do Santo Ofício. Inquisição de Lisboa. Caderno do Promotor, livro 324

ANTT. Tribunal do Santo Ofício. Conselho Geral do Santo Ofício. Habilitações. José. Maço 103, doc. 1465.

ANTT. Tribunal do Santo Ofício. Conselho Geral do Santo Ofício. Habilitações incompletas. Documento 3263.

\footnotetext{
97 VALADARES, Paulo. Nomes de árvores e de animais correspondem a sobrenomes de judeus?. In: Revista de História da Biblioteca Nacional: Dossiê Inquisição. Ano 7, nº 73, Outubro de 2011, p. 29.

98 CARDOSO, Ciro Flamarion. História e textualidade. In: CARDOSO, Ciro Flamarion. VAINFAS, Ronaldo. (orgs.). Novos domínios da história. Rio de Janeiro: Elsevier, 2012. GINZBURG, Carlo. Sinais: Raízes de um paradigma indiciário. In: GINZBURG, Carlo. Mitos, emblemas, sinais: morfologia e história. São Paulo: Companhia das Letras, 1989. GINZBURG, Carlo. $O$ nome e o como. Troca desigual e mercado historiográfico. In: GINZBURG, Carlo. A micro-história e outros ensaios. Lisboa: Difel, 1991.

99 Como bem salienta Janaína Guimarães, nem todo cristão-novo é um criptojudeu em potencial ou "rebelde" que não aceita a conversão cristã: "Vale salientar ainda que a questão da manutenção de práticas costumeiras não necessariamente está atrelada a uma fiel consciência religiosa", SILVA. Op. Cit., 2007, p. 36. No caso de Pernambuco, recortando para "Alagoas Colonial", é importante ter em mente que vários se tornaram "católicos" e não demonstraram (pelo menos documentado, ou denunciado) atividades judaicas.
} 
Instituto Histórico e Geográfico de Alagoas. Sessão de Reservados. 00031-01-03-11. Ordem $3^{\mathrm{a}}$ de Nossa Senhora do Monte do Carmo. Livro de atas. Vila da Alagoas do Sul, 05 Dez, 1728. Informação Geral da Capitania de Pernambuco. In: Anais da Biblioteca Nacional do Rio de Janeiro. Rio de Janeiro: Biblioteca Nacional, Volume XXVIII, 1906.

Ordenações Filipinas: livro II e III. - Lisboa: Fundação Calouste Gulbenkian, 1985

ASSIS, Angelo Adriano Faria de. As "mulheres rabi" e a Inquisição na colônia: narrativas de resistência judaica e criptojudaísmo feminino - os Antunes, macabeus da Bahia (séculos XVI-XVII). In: VAINFAS, Ronaldo. FEITLER, Bruno. LAGE, Lana (org.). A inquisição em xeque: temas, controvérsias e estudos de caso. Rio de Janeiro: EdUERJ, 2006.

AZEVEDO, José Ferreira. Formação Sócio-Econômica de Alagoas, o Período Holandês (1630-1654): Uma Mudança de Rumo. In: CAETANO, Antonio Filipe Pereira (org.). Alagoas colonial: construindo economias, tecendo redes de poder e fundando administrações (séculos XVII-XVIII). Recife: Ed. universitária da UFPE, 2012.

BETHENCOURT, Francisco. História das inquisições: Portugal, Espanha e Itália. Lisboa: Circulo de Leitores, 1994.

BOURDIEU, Pierre. Sobre o poder simbólico. In: BOURDIEU, Pierre. O poder simbólico. Rio de Janeiro: Bertrand Brasil, 2012.

BOXER, Charles. O império marítimo Português. 1415-1825. São Paulo: Companhia das Letras, 2002. CAETANO, Antonio Filipe Pereira. "Existe uma Alagoas Colonial?" Notas preliminares sobre os conceitos de uma Conquista Ultramarina. Revista Crítica Histórica, Ano I, n 1, Junho/2010. http://www.revista.ufal.br/criticahistorica/ (acessado no dia 16/05/2012).

CALAINHO, Daniela Buono. Agentes da fé: familiares da Inquisição portuguesa no Brasil colonial. Bauru: EDUSC, 2006.

CARNEIRO, Maria Luiza Tucci. Preconceito Racial em Portuga e Brasil Colônia: os cristãos-novos e o mito da pureza de sangue. São Paulo: Perspectiva, 2005.

CURVELO, Arthur. O senado da câmara de Alagoas do Sul: Governança e Poder Local no Sul de Pernambuco (1654-1732). Dissertação de Mestrado. Universidade Federal de Pernambuco (UFPE), Programa de pós-graduação em História. Recife, 2014.

DIÉGUES Jr. Manuel. O banguê nas alagoas: traços da influência do sistema econômico do engenho de açúcar na vida e na cultura regional. - $3^{a}$ ed.; prefácio de Gilberto Freyre; capas e vinhetas de Santa Rosa. Maceió, EDUFAL, 2006.

DORIA, Francisco Antonio. Sangue Converso no Brasil Colônia, I. Acessível em: http://www.arquivojudaicope.org.br/arquivos/bancodearquivos. 
GINZBURG, Carlo. O inquisidor como antropólogo: Uma analogia e as suas implicações. In: GINZBURG, Carlo. A micro-história e outros ensaios. Lisboa, Rio de Janeiro: Difel, Bertrand Brasil, 1989.

GINZBURG, Carlo. O nome e o como. Troca desigual e mercado historiográfico. In: GINZBURG, Carlo. A micro-história e outros ensaios. Lisboa: Difel, 1991.

GIZBERT-STUDNICKI, Daviken. A Nação e o Império: o espaço da diáspora marítima portuguesa no Atlântico Luso-Ibérico do século 17. In: SCHWARTZ, Stuart. MYRUP, Erik. O Brasil no império marítimo português. Bauru, Sp: Edusc, 2009.

GODINHO, Vitorino Magalhães. Estrutura da antiga sociedade portuguesa. $4^{a}$ ed. Lisboa: Arcádia, 1980.

GORENSTEIN, Lina. Ter origem judaica era sinônimo de culpa?. In: Revista de História da Biblioteca Nacional: Dossiê Inquisição. Ano 7, nº 73, Outubro de 2011.

HERCULANO, Alexandre. História da origem e estabelecimento da inquisição em Portugal. Porto Alegre: Ed. Pradense, 2002.

HERMANN, Jacqueline. Cristãos-novos. In: VAINFAS, Ronaldo (org.). Dicionário do Brasil colonial (1500 - 1808). Rio de Janeiro: Objetiva, 2001.

ISRAEL, Jonathan I. Judeus sefaradim neerlandeses, política milenarista e a luta pelo Brasil (16451654). In: SCHWARTZ, Stuart. MYRUP, Erik. O Brasil no império marítimo português. Bauru, Sp: Edusc, 2009.

LIMA, Roberto Kant de. Tradição inquisitorial no Brasil contemporâneo: a incessante busca da "verdade real". In: VAINFAS, Ronaldo. FEITLER, Bruno. LAGE, Lana (org.). A inquisição em xeque: temas, controvérsias e estudos de caso. Rio de Janeiro: EdUERJ, 2006.

MACHADO, Alex Rolim. Mercadores da inquisição. Notas sobre estratégias de ascensão social (Alagoas Colonial, c.1674-c.1820). Historien (Petrolina). Ano 4, n 9. Jul/Dez 2013. Acessado em www.revistahistorien.com

MACHADO, Alex Rolim. Classificação e perseguição: os agentes da Inquisição, os negros, pardos e mulatos em uma sociedade escravista (Alagoas Colonial, 1674-1820). Sankofa, Revista de História da África e de Estudos da Diáspora Africana, Ano VII, n XIV, Dezembro /2014.

MELLO, Evaldo Cabral de. 0 nome e o sangue: Uma parábola familiar no Pernambuco colonial. $2^{a}$ edição revista. - Rio de Janeiro: Topbooks, 2000.

MELLO, José Antônio Gonsalves de. Gente da Nação: cristãos-novos e judeus em Pernambuco, 15421654 - 2ª ed. Recife, Fundaj. Editora Massangana, 1996.

MOTT, Luiz. A inquisição em Alagoas. Debates de História Regional (Revista do departamento de história da UFAL), nº 1, Maceió, 1992. 
MOTT, Luiz. Bígamos de Alagoas nas garras da Inquisição. Revista Ultramares. Maceió: Alagoas, GEAC, № 1, Vol. 1, Janeiro-Julho 2012,

NOVINSKY, Anita. A sobrevivência dos judeus na visão de Baruch Spinoza: o exemplo da Paraíba. In: VAINFAS, Ronaldo. FEITLER, Bruno. LAGE, Lana (org.). A inquisição em xeque: temas, controvérsias e estudos de caso. Rio de Janeiro: EdUERJ, 2006.

NOVINSKY, Anita. Os cristãos-novos no Brasil colonial: reflexões sobre a questão do marranismo. Tempo, $n^{0} 11$, Rio de Janeiro.

REGO, João Manuel Vaz Monteiro de Figueiroa. $<<A$ honra alheia por um fio $>>$. Os estatutos de limpeza de sangue no espaço de expressão Ibérica (sécs. XVI-XVIII). Tese de Doutoramento em História Moderna. Minho: Universidade do Minho, Instituto de Ciências Sociais, 2009.

RODRIGUES, Aldair Carlos. Limpos de Sangue: Familiares do Santo Ofício, Inquisição e Sociedade em Minas Colonial. - São Paulo: Alameda, 2011.

ROMANELLI, Cristina. Fogo que arde sem se ver. In: Revista de História da Biblioteca Nacional: Dossiê Inquisição. Ano 7, nº 73, Outubro de 2011.

SALVADOR, José Gonçalves. Cristãos-novos, jesuítas e Inquisição: Aspectos de sua atuação nas capitanias do Sul, 1530-1680). São Paulo: Livraria pioneira editoria; Editora da Universidade de São Paulo, 1969.

SILVA, Janaína Guimarães da Fonseca e. Modos de pensar, maneiras de viver: Cristãos-novos em Pernambuco no século XVI. Dissertação (mestrado em História), Universidade Federal de Pernambuco, Centro de Filosofia e Ciências Humanas, programa de pós-graduação em História: Recife, 2007.

SIQUEIRA, Sonia. A inquisição portuguesa e a sociedade colonial. São Paulo: Ática, 1978.

THOMPSON, Edward P. Costumes em comum. São Paulo: Companhia das Letras, 1998.

TORRES, José Veiga. Da Repressão Religiosa para a Promoção Social. A Inquisição como instância legitimadora da promoção social da burguesia mercantil. In: Revista Crítica de Ciências Sociais, $n^{0} 40$, Outubro 1994.

VAINFAS, Ronaldo. Ideologia e Escravidão: Os letrados e a sociedade escravista no Brasil colonial. Rio de Janeiro: Editora Vozes, [s/d].

VAINFAS, Ronaldo. Jerusalém colonial: judeus portugueses no Brasil holandês. Rio de Janeiro: Civilização Brasileira, 2010.

VALADARES, Paulo. Nomes de árvores e de animais correspondem a sobrenomes de judeus?. In: Revista de História da Biblioteca Nacional: Dossiê Inquisição. Ano 7, nº 73, Outubro de 2011.

WIZNITZER, Arnold. Os judeus no Brasil Colonial. - São Paulo: Livraria Pioneira Editora; Editora da Universidade de São Paulo, 1966. 